\title{
HUBUNGAN PERAN IBU DENGAN PERKEMBANGAN MOTORIK KASAR DAN HALUS USIA 3 TAHUN DI PAUD IMELDA
}

\author{
Bernita Silalahi \\ Universitas Imelda Medan \\ Email: bernitasilalahi01@gmail.com
}

\begin{abstract}
Growth at gross motoric, fine motoric the child 3 year can be told golden year. Hand in glove it's bearing with the mother role in stimulus each; every its chid growth phase. Child growths at the age have to always watch seriously from parent especially mother. If there were any growth delay of child not is immediatelya inspection hence delay of the child can become something serious matter till child grew sup. This research aim toto analyse the relation of role mother with gross motoric, fine motoric the child 3 year. Desain Research used is reseach of survey by using approach of cross sectional, the population is mother and child 3 year in PAUD Imelda Medan a number 30 people with the amount sampel 30 people by using saturated sampling. Independen variable is role mother and variable dependen is growth gross motoric, fine motoric. Measuring instrument of kuesioner and data processingly is editing, coding, scoring, tabulating. The analyse data was by using test of rank spearman. The result this study is $p$ values = $0.906(<0.05)$ were obtained there is a relationship between the role of the mother with the development of gross motor and fine motor skills of children aged 3 years. Suggestion parents continue to improve and carry out their role even though they have to work to support the family economy so that children can develop properly.
\end{abstract}

\section{Keywords: role of mother, growth gross motoric, fine motoric}

\section{PENDAHULUAN}

Perkembangan

merupakan

bertambahnya kemampuan fungsi semua

sistem organ tubuh yang lebih kompleks. Perkembangan yang bersifat reversibel serta kuantitatif yang meliputi kemampuan gerak kasar dan halus (Saputra, 2014).

Usia toddler merupakan usia bermain dan merupakan periode yang sangat penting untuk mencapai pertumbuhan dan perkembangan intelektual secara optimal (Kuncoro, 2013). Menurut Salah satu perkembangan anak yang penting untuk dipantau pada usia 1-3 tahun
(Toddler) (Shabrina Sitoresmi, Kusnanto, \& Krisnana, 2015).

Perkembangan anak ditinjau dari aspek masa atau umur tertentu, meliputi perkembangan fisik-motorik, sosialemosional, moral keagamaan, dan perkembangan kognitif. Perkembangan fisik-motorik anak usia 4-5 tahun terdiri dari perkembangan fisik, motorik kasar, dan motorik halus. Hal ini telah diatur dalam Permendikbud Republik Indonesia No. 137 Tahun 2014 tentang Standar Nasional Pendidikan Anak Usia Dini (Aghnaita, 2017).

Menurut Maryanti, periode penting dalam tumbuh kembang anak adalah 
masa balita pada tahap perkembangan anak dimana pada tahap ini merupakan masa kritis perkembangan daya ingat untuk mengenal sesuatu, oleh karena itu diperlukan rangsangan/stimulus yang tepat agar potensi yang ada pada anak berkembang secara optimal, sehingga pada masa perkembangan ini perlu mendapat perhatian terutama dari orang tua, oleh karena pada masa anak berusia tiga tahun, otak telah membentuk 1.000 triliun jaringan koneksi dimana dua kali lebih aktif daripada otak orang dewasa sehingga dapat menyerap informasi baru lebih cepat (Maryanti, 2011). Perkembangan anak yang penting untuk dipantau pada usia 1-3 tahun (Toddler) adalah perkembangan motorik karena banyak kinerja kognitif yang berakar pada kerberhasilan perkembangan motorik (Sitoresmi, Kusnanto, \& Krisnana, 2015). Lingkungan pengasuhan anak oleh orangtua turut mempengaruhi perkembangan anak (Kementerian Kesehatan RI, 2016) .

Hasil penelitian di India dengan judul family and child correlates of motor development of toddlers in India ada 4,25 kali keterlambatan perkembangan motorik balita yang dirawat dilingkungan rumah yang tidak distimulasi, yang distimulasi dikeluarga mempunyai perkembangan motorik kasar 0,54 kali dibandingkan dengan anak yang diasuh oleh keluarga otoriter dan orang tua yang pesmisif (Sundaram \& Siddegouda, 2016).

Profil Kesehatan Indonesia tahun 2014, mengemukakan jumlah balita 0-2 tahun di Indonesia sebanyak 14.228.917 jiwa, sementara balita dengan interval 14 tahun berjumlah 19.388.791 jiwa. Sekitar 16\% dari anak usia dibawah lima tahun (balita) di Indonesia mengalami gangguan perkembangan saraf dan otak mulai ringan sampai berat. Sekitar 5$10 \%$ anak diperkirakan mengalami keterlambatan perkembangan namun penyebab keterlambatan perkembangan umum belum diketahui dengan pasti, dan diperkirakan sekitar 1-3\% khusus pada anak dibawah usia 5 tahun di Indonesia mengalami keterlambatan perkembangan umum yang meliputi perkembangan motorik, bahasa, sosioemosional, dan kognitif (Kementerian Kesehatan RI, 2015). Sebanyak 49\% balita di negara berkembang mengalami keterlambatan perkembangan motorik kasar dikarenakan pengetahuan ibu yang kurang (Hasanah \& Ansori, 2014).

Studi pendahuluan bulan Oktober 2016 di Kelurahan Mamboro Barat, ada 7 dari 98 anak (7,14 \%) yang mengalami keterlambatan motorik halus pada anak usia 3 tahun belum dapat memegang pensil dengan benar dan menghubungkan garis terputus menjadi suatu objek gambar dengan tepat, 
sedangkan perkembangan motorik kasar mengalami keterlambatan ada 5 dari 98 anak (5,10\%) (Jurana, 2017).

Hasil survei di PAUD Imelda Medan ditemukan sebanyak 4 dari 20 anak yang mengalami keterlambatan motorik halus yaitu belum dapat menarik garis vertikal memegang alat tulis dengan menggunakan ibu jari dan jari lainnya (tidak menggenggam), membuka halaman pada buku, membuat menara dari 8 kubus memegang pensil dan sedangkan perkembangan motorik kasar ada 2 dari 20 anak yang mengalami keterlambatan perkembangan dimana anak sudah berusia 3 tahun belum bisa menendang dan melempar bola.

Keterlambatan perkembangan motorik perlu diantisipasi melalui penilaian atau deteksi dini yang dilaksanakan secara komprehensif. dengan menggunakan instrumen DDST (Denver Development Screning Test sehingga upaya pencegahan, stimulasi, penyembuhan serta pemulihan dapat diberikan dengan indikasi yang jelas pada masa-masa kritis proses tumbuh kembang (Sitoresmi et al., 2015). Perhatian khusus untuk anak untuk mengoptimalkan perkembangan oleh karena itu. diperlukan adanya interaksi antara anak dalam pemberian stimulasi dini. Karena pada masa dewasa akan meningkatkan kemampuan dalam berbagai hal. Pencapaian kemampuan ini membuat dirinya bangga, Hambatan atau kegagalan untuk hal tersebut mengakibatkan anak merasa rendah diri, sehingga pada masa dewasa akan mengalami hambatan dalm bersosialisasi. Berbagai upaya yang diberikan kepada anak berupa rangsangan untuk tumbuh kembangannya terutama untuk otak. Untuk mengoptimalkan otak manusia dilakukan dengan memberikan rangsangan sebanyak mungkin melalui semua alat indera yang ada untuk menghasilkan suatu karya berdasarkan kemampuan diri sendiri (Irmilia, Herlina, \& Hasneli, 2015).

Uraian tersebut diatas membuat peneliti tertarik untuk melakukan penelitian tentang perkembangan motorik kasar dan perkembangan motorik halus pada anak Usia 3 tahun.

\section{METODE}

Jenis penelitian ini penelitian kuantitatif. Lokasi penelitian di di PAUD Imelda jalan Bilal dan PAUD Marelan Medan. Penelitian dilaksanakan pada bulan Maret 2019 sampai dengan Mei 2019.

Populasi dalam penelitian ini adalah seluruh anak yang di PUAD Imelda Medan sebanyak 30 orang. Teknik pengambilan sampel menggunakan sampling jenuh. Sampel penelitian adalah anak yang berusia 3 tahun 
sebanyak 30 orang. 20 orang dari PAUD Imelda jalan bilal dan 10 orang dari PAUD Imelda Marelan Medan.

Teknik pengumpulan data dengan observasi langsung dan wawancara kepada orangtua dan pengisian kuisioner yang menyatakan peran yang dilakukan seorang ibu terhadap anaknya. Kemudian dilakukan pemantauan perkembangan motorik kasar dan halus.

Metode analisa data mendeskripsikan data secara sistematis tentang peran ibu terhadap perkembangan motorik kasar dan motorik halus anak kemudian dilakukan analisis setiap variabel dengan menggunakan Uji Spearman.

\section{HASIL DAN PEMBAHASAN}

Hasil Univariat

Data Umum

Tabel 1. Distribusi Responden Karakteristik Umur Ibu

\begin{tabular}{clrc}
\hline No & Karakteristik & \multicolumn{1}{c}{$\boldsymbol{c}$} & $\boldsymbol{\%}$ \\
\hline 1 & $21-25$ & 7 & 23,3 \\
2 & $26-30$ & 6 & 20,0 \\
3 & $31-35$ & 13 & 13.3 \\
4 & $36-40$ & 4 & 13,3 \\
\hline \multicolumn{2}{c}{ Jumlah } & 30 & 100 \\
\hline
\end{tabular}

Berdasarkan tabel 1 diatas terlihat bahwa distribusi karakteristik mayoritas responden yang interval usianya $31-35$ tahun sebanyak 13 orang $(43,3 \%)$, sedangkan minoritas responden yang interval usianya 36 -40 tahun sebanyak 4 orang $(13,3 \%)$.

\section{Tabel 2. Distribusi Karakteristik Responden Berdasarkan Pendidikan Ibu}

\begin{tabular}{cccc}
\hline No & Karakteristik & $\boldsymbol{f}$ & $\mathbf{\%}$ \\
\hline 1 & D1 & 30 & 100 \\
\hline \multicolumn{2}{r}{ Jumlah } & $\mathbf{3 0}$ & $\mathbf{1 0 0}$ \\
\hline
\end{tabular}

Tabel 2 diatas dapat dilihat bahwa distirbusi karakteristik responden berdasarkan pendidikan semua ibu mengecam perguruan tinggi sebanyak 30 orang $(100 \%)$.

\section{Tabel 3. Distribusi Karakteristik Responden Berdasarkan Perkerjaan}

\begin{tabular}{clrr}
\hline No & Karakteristik & \multicolumn{1}{c}{$\boldsymbol{f}$} & \multicolumn{1}{c}{$\boldsymbol{\%}$} \\
\hline 1 & PNS & 2 & 6,7 \\
2 & Wiraswasta & 12 & 40,0 \\
3 & Pegawai Swasta & 9 & 30,0 \\
4 & IRT & 7 & 23,3 \\
\hline & Jumlah & 30 & 100 \\
\hline
\end{tabular}

Berdasarkan tabel 3 diatas dapat dilihat bahwa distribusi karakteristik mayoritas responden berdasarkan pekerjaan Wiraswasta sebanyak 12 orang (40\%), sedangkan minoritas responden berdasarkan pekerjaan PNS sebanyak 2 orang $(6,7 \%)$

\section{Analisa Bivariat}

Pada penelitian ini data yang diperoleh dapat dianalisa dengan analisis bivariate yaitu untuk mengetahui hubungan peran ibu dengan perkembangan motorik kasar dan motorik halus anak usia 3 tahun di PAUD Imelda Medan tahun 2019. 
Tabel 4. Distribusi

Peran Ibu Tentang
Perkembangan Motorik
Kasar dan Motorik Halus
Anak Usia 3 Tahun

\begin{tabular}{crc}
\hline Peran Ibu & $\boldsymbol{f}$ & \multicolumn{1}{l}{$\boldsymbol{\%}$} \\
\hline Baik & 27 & 90,0 \\
Buruk & 3 & 10,0 \\
\hline Total & $\mathbf{3 0}$ & $\mathbf{1 0 0}$ \\
\hline
\end{tabular}

Berdasarkan tabel 4 diatas jumlah responden yang buruk sebanyak 3 orang $(10,0 \%)$, sedangkan jumlah responden yang baik sebanyak 27 orang $(90,0 \%)$.

\section{Tabel 5. Distribusi Berdasarkan Motorik Kasar dan Motorik Halus Anak Usia 3 Tahun}

\begin{tabular}{lrr}
\hline $\begin{array}{l}\text { Motorik } \\
\text { kasar } \\
\text { Motorik }\end{array}$ & dan & \multicolumn{1}{c}{$\boldsymbol{~}$} \\
Halus & & \\
\hline \multicolumn{1}{c}{ Baik } & 26 & 86,7 \\
$\quad$ Buruk & 4 & 13,3 \\
\hline \multicolumn{1}{c}{ Total } & 30 & 100 \\
\hline
\end{tabular}

Berdasarkan tabel diatas terlihat bahwa distribusi berdasarkan motorik kasar dan motorik halus baik 26 orang $(86,7 \%)$ dan buruk 4 orang $(13,3 \%)$.

Tabel 6. Hubungan Peran Ibu dengan Perkembangan Motorik Kasar dan Motorik Halus Anak Usia 3 Tahun

\begin{tabular}{|c|c|c|c|c|c|c|c|}
\hline \multirow[t]{3}{*}{$\begin{array}{l}\text { Peran } \\
\text { Ibu }\end{array}$} & \multicolumn{4}{|c|}{$\begin{array}{l}\text { Motorik kasar dan } \\
\text { motorik halus }\end{array}$} & \multirow[b]{3}{*}{ Jlh } & \multirow[b]{3}{*}{$\%$} & \multirow{3}{*}{$\begin{array}{c}P \text { - } \\
\text { value }\end{array}$} \\
\hline & \multicolumn{2}{|c|}{ Buruk } & \multicolumn{2}{|c|}{ Baik } & & & \\
\hline & $\mathrm{n}$ & $\%$ & $\mathrm{n}$ & $\%$ & & & \\
\hline Baik & 4 & 13.3 & 13 & 43.7 & 17 & 56.7 & \\
\hline Buruk & 3 & 10 & 10 & 33.3 & 13 & 43.3 & 0,00 \\
\hline Total & 7 & 23.3 & 23 & 76.7 & 30 & 100 & \\
\hline
\end{tabular}

Berdasarkan analisis bivariat dengan menggunakan uji spearman diperoleh hasil sebagai berikut:
Berdasarkan tabel diatas, diketahui bahwa dari 30 responden yang mempersepsikan peran ibu baik sebanyak 27 responden $(90,0 \%)$ dan dengan peran ibu buruk ada sebanyak 3 responden $(10,0 \%)$. Sedangkan dari 30 responden yang mempersepsikan perkembangan motorik kasar dan motorik halus dengan kriteria baik ada 26 responden $(86,7 \%)$ dan dengan kriteria buruk ada sebanyak 4 responden ( 13,3\% ). Uji Spearman's rho diperoleh nilai $p$ hitung $=0,00$ maka $p$ hitung $<p$ value $(0,05)$ maka dikatakan (Ho) ditolak dan (Ha) diterima, artinya kedua variabel secara statistik mempunyai hubungan yang signifikan.

\section{Pembahasan}

Hubungan Peran Ibu dengan Perkembangan Motorik Kasar dan Motorik Halus Anak Usia 3 Tahun

Hasil penelitian ini menunjukkan bahwa peran ibu berhubungan dengan perkembangan motorik kasar dan motorik halus anak usia 3 tahun, yang ditunjukkan dengan ibu dengan peran baik memiliki anak dengan perkembangan baik sebanyak 13 orang $(43,47 \%)$, sedangkan ibu dengan peran buruk memiliki anak dengan perkembangan motorik kasar dan halus yang buruk juga yaitu sebanyak 3 $(10 \%)$. Berdasarkan hasil tersebut, dapat diketahui bahwa peran sangat dibutuhkan dalam perkembangan motorik kasar dan halus anaknya. 
Tingginya angka yang menunjukkan motorik halus dan motorik kasar baik dikarenakan ibu memahami akan perannya dan mengaplikasikan terhadap anaknya dirumah di barengi dengan kesiapan ibu untuk memfasilitasi permainan yang pariatif dan edukatif sesuai tingkat usia.

Berdasarkan hasil penelitian adanya motorik halus dan motorik kasar yang kurang baik sesuai usia 3 tahun dikarenakan oleh karena ibu kurang memberikan stimulus terhadap anaknya oleh karena ibu terlalu sibuk bekerja oleh karena ibu tidak selalu menemani anaknya bermain.

Hal ini seperti yang dijelaskan oleh Jurana bahwa salah satu faktor yang paling mempengaruhi perkembangan motorik anak adalah lingkungan pengasuhan, di mana mayoritas ibu yang memberikan dan memenuhi kebutuhan anaknya baik dalam hal kebutuhan fisik, perhatian dan kasih sayang, serta stimulus untuk perkembangannya (Jurana, 2017).

Selain itu, orangtua khususnya ibu juga berperan sebagai pendidik bagi anak-anaknya sehingga anak-anaknya dapat berkembang dengan baik dari segi fisik, mental, dan sosial-spiritual (Irmilia et al., 2015). Dengan demikian, dapat diketahui bahwa Ibu yang dapat menjalankan perannya dengan baik, tentu dapat menjadi pendidik yang baik juga untuk anak-anaknya sehingga menjadi anak yang cerdas dan mandiri.

Peran ibu sangat dibutuhkan terutama dalam pemberian stimulasi pada anaknya dalam masa perkembangan khususnya pada masa golden age. Stimulasi yang baik dari orangtua merangsang anak untuk mengenal pengetahuan dan keterampilan baru sehingga anak mengalami peningkatan kecerdasan, termasuk dalam peningkatan kemampuan motorik anak (Jurana, 2017).

Perkembangan motorik Anak terbentuk melalui sebuah perkembangan dalam proses belajar. Masa perkembangan awal, anak menunjukkan rasa aman dalam keluarganya apabila kebutuhannya terpenuhi oleh lingkungan. Anak mengeksplorasi dirinya melalui cara sentuhan, dengan mengeksplorasi anak akan belajar. Sebaliknya apabila anak merasa tidak aman dalam lingkungan keluarga, anak menghabiskan tumbuh kembang di luar dan tidak terpantau. Hal ini didukung oleh penelitian yang dilakukan di India yang menyatakan bahwa balita yang dirawat di lingkungan rumah yang tidak memberikan stimulasi akan mengalami keterlambatan 4,25 kali mengalami keterlambatan perkembangan motorik dan 4,75 kali mengalami keterlambatan halus dibandingkan dengan balita yang dirawat di lingkungan rumah yang 
memberikan stimulasi (Sundaram \& Siddegouda, 2016).

Peran ibu sebagai suri teladan, ibu harus memiliki nilai-nilai baik yang tercermin dalam sikap dan perilakunya. Hal ini penting artinya bagi proses belajar anak dalam usaha untuk menyerap apa yang ditanamkan.

\section{KESIMPULAN DAN SARAN}

\section{Kesimpulan}

Berdasarkan penelitian mengenai hubungan peran ibu dengan perkembangan motorik kasar dan motorik halus anakusia 3 tahun di PAUD Imelda Medan dapat disimpulkan bahwa terdapat hubungan antara peran ibu dengan perkembangan motorik kasar dan motorik halus anak usia 3 tahun di paud Imelda medan

Berdasarkan hasil angka koefisien korelasi diatas bernilai posistif yaitu 0.00 sehingga hubungan kedua variabel tersebut bersifat searah (jenis hubungan searah) dan berdasarkan hasil analisa uji Spearman didapatkan hasil output uji spearman 0,00 dengan demikian dapat diartikan bahwa semakin baik peran ibu maka akan semakin baik pula tingkat perkembangan motorik kasar dan motorik halus anak umur 3 tahun di PAUD Imelda medan. Dan untuk melihat tingkat kekuatan antara hubungan peran ibu dengan perkembangan motorik kasar dan motorik halus anak usia 3 tahun di paud Imelda medan didapatkan hasil output uji Spearman 0,906.

\section{Saran}

\section{Bagi orang tua}

Diharapkan untuk orang tetap dapat meningkatkan hubungan peran terutama pada ibu untuk perkembangan motorik kasar dan motorik halus yang lebih baik. karna tumbuh kembang anak yang baik dari hasil peran orang tua yang baik.

\section{Bagi guru}

Diharapkan kepada dewan guru mempunyai keterampilan dan pengetahuan berkomunikasi dengan orang tua. Hal ini dikarenakan pemahaman guru mengenai peran ibu akan membantu dalam memberikan pelayanan dan bimbingan pada anak sehingga perkembangan motorik kasar dan motorik halus anak berkembang dengan baik.

\section{Bagi peneliti selanjutnya}

Dapat dijadikan data dasar untuk mengadakan penelitian selanjutnya yang lebih baik dengan menambahkan jumlah responden, megubah jenis penelitian dan menambah variabel.

\section{DAFTAR PUSTAKA}

Aghnaita, A. (2017). Perkembangan Fisik-Motorik Anak 4-5 Tahun Pada Permendikbud no. 137 Tahun 2014 (Kajian Konsep Perkembangan Anak). Al-Athfal: Jurnal Pendidikan Anak. https://doi.org/10.14421/alathfal.2017.32-09

Hasanah, N., \& Ansori, M. N. (2014). 
Hubungan Tingkat Pengetahuan Ibu Dengan Perkembangan Motorik Kasar Anak Usia ( 3 - 5 Th ). Jurnal Kebidanan, 6(2), 7. https://doi.org/10.30736/midpro.v6i2. 42

Irmilia, E., Herlina, \& Hasneli. (2015). Hubungan Peran Orang Tua Terhadap Perkembangan Psikososial Anak Usia Sekolah. Jom, 2(1), 551557.

https://doi.org/10.1017/CBO9781107 415324.004

Jurana. (2017). Perkembangan Motorik Kasar dan Halus pada Anak Usia 1-3 Tahun. Jurnal Ilmiah Kedokteran, 4(3), 47-63.

Kementerian Kesehatan RI. (2015). Profil Kesehatan Tahun 2014. Kementerian Kesehatan Republik Indonesia.

https://doi.org/10.1159/000324200

Kementerian Kesehatan, RI. (2016). Pedoman pelaksanaan stimulasi, deteksi, dan intervensi dini tumbuh kembang anak. Jakarta: Kemenkes RI.

Kuncoro, D. H. (2013). Hubungan antara stimulasi ibu dengan perkembangan motorik halus dan kasar pada anak usia todler di PAUD mekarsari desa pucangombo tega lombo pacitan. Universitas Muhamadiyah Surakarta.

Maryanti. (2011). Buku ajar neonatus, bayi \& balita. Jakarta: Prenada Media Group.

Saputra, L. (2014). Pengantar asuhan neonatus, bayi, dan balita. Tangerang Selatan: Bina Putra Aksara Publiser.

Sitoresmi, S., Kusnanto., \& Krisnana, I. (2015). Perkembangan Motorik Anak Toddler pada Ibu Bekerja dan Ibu Tidak Bekerja. Jurnal Pedomaternal, 3(1).

Sitoresmi, Shabrina, Kusnanto, \& Krisnana, I. (2015). Perkembangan motorik anak toddler pada ibu bekerja dan ibu tidak bekerja. Jurnal Pediomaternal, 3(1). Retrieved from http://www.journal.unair.ac.id/PMNJ
@ perkembangan-motorik-anaktoddler-pada-ibu-bekerja-dan-ibutidak-bekerja-article-8459-media130-category-3.html

Sundaram, B., \& Siddegouda, S. Y. (2016). Family and child correlates of motor development of toddlers in India. Int J Cur Res Rev, 5(2). 